\title{
EGFR Protein Overexpression
}

National Cancer Institute

\section{Source}

National Cancer Institute. EGFR Protein Overexpression. NCI Thesaurus. Code C39716.

A molecular genetic abnormality indicating the presence of an abnormally high level of EGFR protein. 